\title{
Article
}

\section{Sustainable workplaces and building user comfort and satisfaction}

Smith, Andrew James and Pitt, Michael

Available at http://clok.uclan.ac.uk/2748/

Smith, Andrew James and Pitt, Michael (2011) Sustainable workplaces and building user comfort and satisfaction. Journal of Corporate Real Estate, 13 (3). pp. 144-156. ISSN 1463-001X

It is advisable to refer to the publisher's version if you intend to cite from the work.

For more information about UCLan's research in this area go to

http://www.uclan.ac.uk/researchgroups/ and search for < name of research Group>.

For information about Research generally at UCLan please go to

http://www.uclan.ac.uk/research/

All outputs in CLoK are protected by Intellectual Property Rights law, including Copyright law. Copyright, IPR and Moral Rights for the works on this site are retained by the individual authors and/or other copyright owners. Terms and conditions for use of this material are defined in the policies page.

\section{CLoK}

Central Lancashire online Knowledge www.clok.uclan.ac.uk

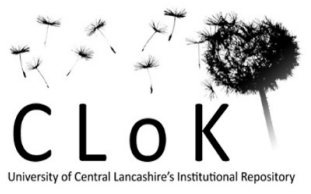




\title{
Sustainable workplaces and building user comfort and satisfaction
}

Andrew Smith

University of Central Lancashire

Ajsmith3@uclan.ac.uk

Michael Pitt

University College London

Michael.Pitt@ucl.ac.uk

\begin{abstract}
This paper examines the role of sustainable buildings in providing healthy workplaces in physical and perceptual terms, taking the form of a literature review. The paper considers the history of sustainable development in the built environment and its rationale, then widening the scope to consider sustainable, healthy and productive workplaces.
\end{abstract}

Sustainable construction has focused on environmental sustainability but this may have contributed to improved health, satisfaction and wellbeing amongst building users. Sick building syndrome and poor indoor air are contributory factors to ill health and reduced productivity but this paper suggests that sustainable building practices will reduce these effects, improving the quality of buildings for their occupants.

This paper argues that building performance measures need to take account of people factors such as employee perceptions and also that the design of workplaces should be regarded as a strategy for productivity enhancement. Management issues should be considered in the design of workplaces. The paper concludes that further research is required into the role of sustainable construction in providing healthy buildings.

\section{Key Words}

Sustainable buildings, health, workplace perceptions, productivity

\section{Introduction}

This paper examines the role of sustainable buildings in contributing to user satisfaction in physical and perceptual terms. Some research suggests that occupants of environmentally sustainable buildings feel better psychologically, although this area of research is in its infancy.

With increasing sustainability legislation worldwide, this is an important area of research, which may help to provide a business case for achieving occupant health and productivity aims as well as environmental and economic aims through sustainable development. 
Sustainable construction has focused on environmental sustainability but this may have contributed to improved health, satisfaction and wellbeing amongst building users. Sick building syndrome and poor indoor air are contributory factors to ill health and reduced productivity but this paper suggests that sustainable building practices will reduce these effects, improving the quality of buildings for their occupants.

This paper takes the form of a literature review, firstly considering the history of and rationale for sustainable development in the built environment and argues that building performance measures need to take account of people factors such as employee perceptions and also that the design of workplaces should be regarded as a strategy for productivity enhancement. The paper concludes that further research is required into the role of sustainable construction in providing healthy, productive buildings with high occupant satisfaction scores.

If rigorous research shows that substantial productivity gains can be achieved in sustainable buildings, this will help to build the business case to show the financial viability of investment in green buildings at the corporate level. However, substantial further research is required towards this.

\section{Sustainable development in the built environment}

The Brundtland Report produced the most widely used definition of sustainable development as 'development that meets the needs of the present without compromising the ability of the future generations to meet their own needs' (WCED, 1987). Sustainable development involves three key factors; environmental responsibility, economic profitability and social awareness and achieving the right balance between them (CIRIA, 2006). The property and construction industry in the UK contributes to all three elements of sustainable development in a number of ways.

Traditionally however, sustainable development issues in the property and construction industry have tended to focus on the importance of 'sustainable construction'. Dickie and Howard (2000) define sustainable construction as 'the contribution of construction to sustainable development'. However, in practice it appears that the focus is mainly directed at environmental sustainability. The property and construction industry impacts the environment in its contribution to waste creation, energy use, water use, recycling and re-use of materials, pollution and biodiversity. Environmentally the industry has the largest impact and, therefore, has the biggest opportunity to make a difference. The industry also contributes economically to the UK with employment, an emphasis on profitable growth and socially responsible investment (SRI). Finally, the social impact of the built environment affects the way society lives and works. Consequently the need to build sustainably is important as 'what we build today will provide the built environment of the future and will influence the ability of future generations to meet their needs' (ibid).

The policy of the UK Government for sustainable development is set against Global initiatives. In 1992 the Earth Summit (UN Conference on Environment and 
Development), held in Rio de Janeiro, discussed the ways of achieving sustainable development. The Summit set out 27 principles supporting sustainable development and agreed an action plan; Agenda 21. Part of this was for all countries to develop national sustainable development strategies. In 1994 the UK was one of the first countries to do so (DTI, 2004).

The Kyoto Protocol is an agreement made under the United Nations Framework Convention on Climate Change (UNFCCC). In 1999 targets were agreed worldwide on the reduction of greenhouse gas emissions; the target for the EU was to reduce emissions to 8\% below 1990 levels by 2008-2012 (ibid). The UK has set itself the target of reducing these gas emissions by $8-12 \%$ by 2010 . In response to these global agreements sustainability has been high on the Government's agenda. In 1999 it published a new strategy document; 'A better quality of life - strategy for sustainable development for the United Kingdom'. This report identified four main aims of the Government strategy:

- Social progress which recognises the needs of everyone;

- $\quad$ Effective protection of the environment;

- $\quad$ Prudent use of natural resources;

- Maintenance of high and stable levels of economic growth and employment.

The 2009 United Nations Climate Change Conference and the associated Copenhagen Accord was one of the most recent global climate change summits, which has a stated aim of keeping global warming to below $2^{\circ} \mathrm{C}$, but some authors argue that national emissions-reduction pledges, which accompany the document are insufficient to meet the objective (Rogelj and Meinshausen, 2010).

The goal of the Copenhagen meeting was to finalise a legally binding international agreement, which had been under negotiation since the United Nations Climate Change Conference in Bali in 2007 and was intended to fill the gap when the Kyoto Protocol expires in 2012 (Sandler and Schiffman Kymer, 2010). Although the conference fell short of expectations, Sandler and Schiffman Kymer argue that the resulting Accord did move climate change legislation in the right direction.

The UK Government's strategy for sustainable construction was published in 2000 by the Department of the Environment, Transport and the Regions (DETR) (now Department of the Environment, Food and Rural Affairs (DEFRA)) which follows from the 1999 priorities (DETR, 2000). The document sets out ways that the construction industry could contribute to the achievement of more sustainable development. These are:

- $\quad$ Being more profitable and more competitive;

- Delivering buildings and structures that provide greater satisfaction, well-being and value to customers and users;

- $\quad$ Respecting and treating its stakeholders more fairly;

- Enhancing and better protecting the natural environment;

- Minimising its impact on the consumption of energy (especially carbon based energy) and natural resources. 
These provide the framework for discussion on the environmental impact of sustainable construction. The latest Strategy for Sustainable Construction (2008) builds on the principles developed in 1999 by emphasising the need for a behavioural change in the industry. The strategy aims to move towards 'lean construction', which not only supports the environmental objectives, but can improve profitability of the overall project. Investment is critical to any construction project and sustainability issues are becoming a factor in this area too.

\section{Sustainable construction to sustainable workplaces}

While environmental considerations in the built environment have tended to focus on building 'green', and are often given prominence by organisations, health and wellbeing considerations of the workplace are more difficult to quantify and have tended to be given less attention. However, there is increasing recognition that achieving sustainable development in the built environment goes beyond sustainable construction, to focusing on sustainable workplaces.

With suggestions that employee disengagement is increasing (Pech and Slade, 2006), it is important to provide workplaces that positively influence employee well-being. Engaged employees have an energetic and effective connection with their work and look upon it as challenging rather than stressful (Bakker et al., 2008). Pech and Slade (2006) argue that the focus is often on symptoms of disengagement such as distraction, lack of interest, poor decision-making and high absence rates, rather than the root causes. Smith and Pitt (2008) suggest that the workplace may be a key root cause.

Research has indicated that improving the working environment reduces complaints and absenteeism and increases productivity (Roelofsen, 2002). Workplace satisfaction has been associated with job satisfaction (Wells, 2000) and perceptions of workplace quality have a significant effect on building users’ psychology.

Fleming (2004) argues that the current use of quantitative building performance measures fails to account for the effect of occupiers' perceptions of their environment and that facilities managers currently see buildings as containers of products rather than containers of people, with idiosyncratic thoughts and perceptions. He proposes that analysis of actual perceptions against ideal or expected perceptions would provide a platform for establishing a set of performance indicators that move away from the current paradigm and provide an alternative platform for analysis.

Studies have shown that job resources are positively associated with work engagement and these include physical, social or organisational aspects of the job that may reduce job demands, assist achievement of work goals or stimulate personal growth, learning and development (Bakker et al., 2008). It is possible, therefore, that the workplace could be considered a job resource, which either positively or negatively impacts upon engagement.

Lee and Brand (2005) found a positive correlation between perceived personal control over the physical environment and self-reported job satisfaction. They also found that perceived personal control was positively related to workplace satisfaction. Where 
people are tied to workplaces in open plan layouts, it can be harder to achieve the comfort levels they prefer, so with more control over their environmental conditions and use of time and space in the building, tend to be happier (Leaman and Bordass, 2007). However, Leaman and Bordass (2007) also point out that, while people like the ability to tweak and fine-tune conditions to their liking, too much choice can annoy them as they do not want to spend too much time adjusting building controls.

Availability and use of personal controls may be higher in green buildings, but this does not always lead to optimal comfort conditions (Brown and Cole (2009).

Warnock (2007) argues that environmental assessment tools such as BREEAM in the UK and LEED in the US are useful in guiding industry towards best practice and improving the quality of buildings for occupants. This is in line with the UK government's strategy for sustainable construction (DETR, 2000). Indeed, BREEAM rigorously assesses parameters including health and wellbeing (BRE, 2011).

A healthy working environment can be defined as an environment that is free from negative health contaminants and where safety hazards are reduced to the minimum. A healthy working environment will contribute to staff feelings of well-being. Therefore, indoor air quality (IAQ) is one of the key concerns in workplaces and is an area where sustainable building methods may have considerable impact.

\section{Health and wellbeing in sustainable buildings}

One of the key negative health aspects of buildings is Sick Building Syndrome. This phenomenon emerged as a recognised workplace problem in the 1980s (Tong and Leaman, 1993). With the move to air-conditioned buildings over the last 50 years or so and more recently, energy-efficient buildings, the environmental conditions for Sick Building Syndrome have been created. Symptoms of illness relating to sick building syndrome include eye, nose and throat irritation; dry skin and mucous membranes; skin rash; mental fatigue; headaches and airway infections; cough; hoarseness, wheezing, itching, hyper-sensitivity; nausea and dizziness (Rooley, 1997). These symptoms will generally disappear shortly after leaving the building. ThomasMobley et al. (2005) define a sick building as:

"one in which 20 per cent or more building occupants experience similar acute health effects that appear to be linked to time spent in a building, but no specific illness or cause can be identified.”

Sick Building Syndrome can be caused by poor ventilation, enabling the build up of indoor pollutants. Tong and Leaman (1993) also point out that management can create an organisational culture which increases the sensitivity of the building population to environmental conditions. For example, by setting inadequate environmental performance standards, lacking suitable building performance data, failing to anticipate the consequences of change, ignoring job stress factors or responding slowly to environmental complaints.

Volatile Organic Compounds (VOCs) are present in buildings, particularly in new or recently refurbished buildings. They are typically associated with materials derived 
from petroleum products and arise in off-gassing from a variety of building products, furnishings, cleaning products (Williams, 1998), paints, adhesives, carpeting, upholstery, panelling, plastic, vinyl, copying machines, computers and hundreds of other office products (Wolverton and Wolverton, 1993). He et al. (2007) found VOCs to be emitted in varying amounts by the lubricating oil in mechanical parts of office printers. These include substances such as Benzene and Formaldehyde, which in low concentrations can cause skin irritation and dry throats but in higher concentrations are linked to cancer (Guo et al., 2004; Wolverton et al., 1989; Rooley, 1997).

Guo et al. (2004) carried out a study of indoor environments in Hong Kong to risk assess exposures to individual VOCs in different environments, including offices. They found that benzene, styrene, methylene chloride, chloroform, trichloroethene and tetrachloroethene were the most prevalent VOCs in selected indoor environments.

In the Hong Kong study (Guo et al., 2004), benzene was found to account for approximately 40 per cent of the lifetime cancer risk associated with each category of indoor environment. Benzene is a natural component of crude oil (Karakitsios et al., 2007) and is found in a range of office products. Styrene also accounts for a large proportion of lifetime cancer risk in offices (Guo et al., 2004).

Formaldehyde is a colourless gas and is present in urea formaldehyde foam insulation (UFFI), particle board, adhesives, some textiles (Rooley, 1997), resins used in woodbased products and a variety of other widely used products (Williams, 1998). It is a suspected carcinogen, an irritant (particularly of the eyes) and an asthmogen (Rooley, 1997). It has been classified as a mutagen and in Germany, indoor formaldehyde concentrations in air have often been found to be higher than the legal German tolerance value (Giese et al., 1994).

Williams (1998) points out that building occupants may be exposed to many pollutants simultaneously and although exposure to individual contaminants may be extremely low, the combined effects over time may be much more significant. Allergen sensitisation occurs when the body is exposed to an allergen resulting in an altered capacity to react to that substance. Further exposure can lead to immunoreaction such as asthma, rhinitis, alveolitis, dermatitis or eczema (Rooley, 1997). Some allergens found in offices are (ibid):

- Insect detritus.

- House dust mite excreta.

- Fungal spores (Penicillium, Trichoderma, Mucro, Cladosporium, Stemphylium, Aspergillus alternaria).

- Isocyanates (toluene, hexamethylene, diphenylmethane, napththalene, formaldehyde, phthalate anhydrides, natural resins, enxymes, animal proteins).

Contaminated air may also result from contamination of fresh air intakes such as emissions from the building itself or other nearby buildings; vehicle exhaust from street traffic, car parks and loading docks; contamination from industry, streets and construction sites; or outdoor contaminants from other sources being transferred to unexpected situations by wind currents (Williams, 1998). A further example of indoor air pollution is airborne particles, which were found to be produced in significant quantities from office printers (He et al., 2007). They concluded that toner 
cartridge and the age of the cartridge could be the most significant factors affecting printer emissions.

Resolution of indoor air problems has tended to focus on ventilation. Costa and James (1995) point out that there is a move towards naturally ventilated buildings with opening windows, effective use of daylight, reduced energy consumption and maintenance costs and that there is a broad shift in favour of more natural, biologically oriented building service solutions as opposed to chemically oriented, highly engineered solutions. Similarly, Smith et al., (1998) argue that buildings which are designed and constructed to be environmentally benign are healthier for users in comparison to contemporary buildings, many of which, they argue, are environmentally damaging and unhealthy for their users.

As a result of the importance of air quality in buildings, a great deal of attention has been given to the selection of building materials for enhanced indoor air quality in several of the green building rating systems and standards (Alevantis and Levin, 2011). For example, the new BREEAM 2011 Technical Manual includes a section on indoor air quality within a comprehensive chapter on health and wellbeing, including issues such as visual comfort, thermal comfort, water quality, acoustic performance and safety and security (BRE, 2011).

Some research has shown that sustainable buildings may be healthier than buildings constructed using traditional methods and materials. Palanivelraja and Manirathinem (2010) contend that sustainable buildings use resources such as energy, water, materials and land more efficiently, with more natural light and better air quality so that these buildings contribute to improved health, comfort and productivity.

Singh et al (2010) investigated changes in employees' health perceptions in areas such as asthma and allergies, following a move from traditional to green offices, assessed using LEED. Overall they found substantial reductions in self-reported absenteeism and affected work hours resulting from perceived improvements in health and wellbeing and that employees perceived a positive effect of their new environment on productivity.

Green solar architecture was pioneered in Germany by architect Dieter Schempp, whereby the indoor climate in the building is regulated using plants (Freeman, 2008). By using trees and plants within buildings, the desirable aspects provided by natural elements outlined above may be realised. Green solar architecture provides a possible methodology for achieving healthy buildings through sustainable building design and construction.

\section{Sustainable workplace influences on productivity}

A range of literature exists relating to different elements of the workplace in contributing to productivity such as:

- Personal control

- Privacy 
- Interior planting

- Personalisation

- Colour

- Windows and lighting.

Lee and Brand (2005) found a positive correlation between perceived personal control over the physical environment and self-reported job satisfaction. They also found that perceived personal control was positively related to workplace satisfaction. However, Veitch and Gifford (1996) found that although choice led to perceptions of increased control, it also led to a performance decrement among the participants in their trial. They suggest self-presentation and fear of failure were heightened in those participants who were given a choice and that these findings have implications for the relationship between facilities managers and building occupants (Veitch and Gifford, 1996).

While privacy is one of the key complaint areas, especially in open plan offices (Duvall-Early and Benedict, 1992; Goodrich, 1982; Kupritz, 1998). There are, however, positive distractions, such as trees, plants and water (James, 2007) that may be incorporated into buildings to improve workplace quality and productivity. Goodrich (1982) also advocates using large plants to increase privacy perceptions. He states that workers agreed that plants made the office more pleasant and informal and this seemed to reduce their need for high privacy levels. Shibata and Suzuki (2002) found that peoples' mood may be affected by plants and

Kaplan (1993) asserted that those with a view of nature such as trees and greenery were more satisfied and that even a short exposure to a natural setting can serve a restorative function:

"Those with a view of nature felt less frustrated and more patient, found their job more challenging, expressed greater enthusiasm for it, and reported higher life satisfaction as well as overall health" (ibid).

Kaplan (1993) suggests that having natural areas at the workplace can be useful for views or direct involvement such as lunch areas and areas to walk. Bringing nature into buildings is becoming increasingly popular with the use of landscaped atria and "streets" within buildings.

Larsen et al (1998) add support for workplace plants, finding that office plants increased participants' perceptions of office attractiveness and comfort. Surprisingly however, they found that productivity reduced with greater numbers of plants. They suggest this may be due to the repetitive nature of the task in their study.

Hanie et al (2010) suggest that natural elements play an important role in buildings and can simply the occupants' psychological behaviour and wellbeing. However, while sustainable buildings are likely to utilise natural materials to a greater extent, Hanie et al stop short of making this connection. Their suggested solutions to improve indoor environmental quality include increasing ventilation rates, pollutant source removal, air cleaning, flexible design, education and communication among 
occupants, management and maintenance personnel and location of the building (ibid.), which are relevant considerations in any building, sustainable or otherwise.

Green solar architecture is an example of sustainable buildings utilising natural elements, whereby the indoor climate in the building is regulated using plants (Freeman, 2008). By using trees and plants within buildings, the desirable aspects provided by natural elements outlined above may be realised. Green solar architecture provides a possible methodology for achieving healthy buildings through sustainable building design and construction.

Recent studies have shown perceptual benefits of indoor plants in terms of reductions in pressure, health concerns, increases in morale, preference for plants, productivity, privacy, comfort and a substantial decrease in sickness absence following the installation of plants (Smith et al., 2011) as well as improvements in indoor air quality (Smith and Pitt, 2011).

Colour is an important determinant of user perceptions but it appears often to be overlooked. Wright (2005) points out that workplace colour decisions will influence staff motivation and absenteeism as well as portraying a certain image to clients. Stone and English (1998) undertook a study of the effects of task type, colour and the presence of a poster on subjects' mood, satisfaction and performance. They studied the effect of red and blue partitions in the workspace and found that perceived privacy was higher in the blue partitions than in the red. A study of red, white and green offices (Kwallek and Lewis, 1990) found that subjects preferred working in the white environment but significantly more errors were made in the white office than in the red. However, subjects working in the white office rated it less distracting than those working in the red office.

Stone and English (1998) found that perceived room temperature was affected by colour. Those working in blue partitioned areas perceived it to be cooler than those in red workspaces. This may have sustainability implications in terms of energy use. Building users could potentially be made to feel cooler in warm climates and vice versa. The detailed psychological effects of colours are beyond the scope of this paper but clearly workplace colour is an important consideration and one which can significantly influence organisational performance.

Access to windows and artificial lighting will also affect the perceptions of building users. There tends to be a strong preference for windows among occupants, however, Stone and Irvine (1994) found no evidence that windows effect higher performance levels. Their study found that a windowless room appeared to reduce stimulation from the environment, which was beneficial for tasks such as filing but potentially limiting for tasks benefiting from stimulation such as creative tasks (ibid). Goodrich (1982) reported that having a window was psychologically important to workers as it provided more mental freedom, a chance to get away from the problem to gain new insight and a broader perspective as well as reducing fatigue and stress. However, negative effects were sunlight producing glare on computer screens and solar heat gain. 
However, while this provides an interesting insight into some productivity considerations in workplace design, these factors may not be immediately recognised as elements of environmentally sustainable construction. Closer analysis may yield some possibilities though. The BREEAM Offices 2008 Assessor Manual (BRE, 2009) includes a section on health and wellbeing, including factors such as access to daylight, external views, high frequency lighting, lighting levels, occupant control over lighting, natural ventilation, indoor air quality, volatile organic compound emissions, thermal comfort, microbial contamination and acoustic performance. This suggests that the majority of the considerations outlined above are closely linked to sustainable buildings in terms of health and wellbeing considerations.

Research has also suggested that user perceptions may be different in sustainable buildings, compared to conventional buildings. Baird and Oosterhoff (2008) studied user perceptions in a range of sustainable commercial and institutional buildings in eleven countries. They found that occupants judged these buildings to be healthier and they perceived themselves to be more productive in sustainable buildings. They also found that several factors had a high correlation with health, such as productivity, building design, comfort overall, space in the building, summer temperatures, winter conditions, lighting, noise and winter temperatures.

Similarly, Leaman and Bordass (2007) carried out occupant surveys in 177 buildings in the UK and found that green-intent buildings score better on summary variables for ventilation/air in summer and winter, comfort overall, perceived productivity and possibly temperature in winter. However, when the data is examined in more detail, the picture is less optimistic. The summary variables take the context though, and occupants appear to be more forgiving of green buildings, perhaps because features that they like are present, such as outside views, shallower plan forms, more control and better use of natural light and often more care taken in their briefing, design and management (Leaman and Bordass, 2007).

Singh et al (2010) claim that the improvements they found in perceived productivity in those moving into green buildings could result in an additional 38.98 work hours per year for each occupant of a green building.

However, some studies have found little improvement in perceptions and sometimes building users may be less satisfied in sustainable buildings (Zeiler and Boxem, 2009).

Clearly, much greater research is required in this area and it is suggested that using perceptions of green buildings as a central theme of future research could yield some interesting results and may help to move towards a more convincing business case for investment in sustainable buildings. 


\section{Conclusions}

This paper has reviewed sustainability in buildings from a high level, global perspective before considering how policy translates into the provision of sustainable workplaces.

Sustainable development has come to the fore over the last twenty to thirty years, largely due to increasing legislation worldwide. Sustainable construction has tended to focus mainly on environmental sustainability, but it is likely that this focus has also brought about sustainable workplaces in terms of users' health, satisfaction and wellbeing. In this regard, there is a need for building performance measures to take account of people-oriented factors such as employee perceptions. By improved management of perceptions, productivity gains may be realised. Environmental assessment tools such as BREEAM may help improve the quality of buildings for occupants.

Sick building syndrome and poor indoor air quality can adversely affect health and productivity, but sustainable building practices such as natural ventilation, use of more natural materials, access to daylight and external views will reduce the likelihood of poor indoor air, as well as providing psychological benefits such as those provided by access to nature in the workplace.

The paper argues that workplaces designed to be environmentally sustainable should also be regarded as a strategy for productivity enhancement and management issues need to be considered in the design of work space. Evidence suggests that building users perceive sustainable buildings as being healthier and more conducive to productivity, also being more forgiving of such buildings. Substantial further research is required in this complex area of human perception.

This paper suggests that healthy buildings can be achieved through sustainable construction approaches. However, whilst the initial outcomes of existing research look promising, substantial research is now required into the areas of indoor comfort and building user perceptions in sustainable buildings due to the knowledge gap in this area.

\section{References}

Alevantis, L., Levin, H. (2011). “Materials-related IAQ.” ASHRAE Journal, March 2011, pp. 86-88.

Baird, G., Oosterhoff, H. (2008) “Users' perceptions of health in sustainable buildings worldwide.” Healthy and Creative Facilities, Proceedings of the CIB W70

Conference in Facilities Management, Edinburgh, UK, $16^{\text {th }}-18^{\text {th }}$ June 2008, pp. 649 - 656.

Bakker, A.B., Schaufeli, W.B., Leiter, M.P., Taris, T.W. (2008) "Work engagement: An emerging concept in occupational health psychology.” Work \& Stress, Vol. 22, No. 3, pp. $187-200$. 
BRE (2009) “BREEAM Offices 2008 Assessor Manual.” BRE Environmental and Sustainability Standard, BES 5055: Issue 3.0. Building Research Establishment.

BRE (2011) "BREEAM New Construction non-domestic buildings: Technical Manual. SD5073-2.0:2011: Issue 1. Building Research Establishment.

Brown, Z., Cole, R.J. (2009) “Influence of occupants' knowledge on comfort expectations and behaviour.” Building Research and Information, Vol. 37, No. 3, pp. 227-245.

CIRIA (2006) Compliance+ Sustainability. [online] Available at: http://www.ciria.org/complianceplus/sustainability.htm

Costa, P., James, R.W. (1995) "Constructive use of vegetation in office buildings." Plants for People Symposium, The Hague, Netherlands, 23 November 1995.

Available at:

http://www.healthygreenatwork.org/index_en.cfm?act=artikelen.details\&varart=18 [Accessed 30/12/08].

DETR (2000). Building a Better Quality of Life; A Strategy for more Sustainable Construction. Department of the Environment, Transport and the Regions. [online]. Available at: http://www.dti.gov.uk/construction/sustain/bql/pdf/sus_cons.pdf

Dickie, I and Howard, I (2000). BRE Digest 446: Assessing environmental impacts of construction. BRE Centre for Sustainable Construction.

DTI (2004). Sustainable Construction Brief 2. Department of Trade and Industry. H.M.S.O.

Duvall-Early, K., Benedict, J. (1992) “The relationships between privacy and different components of job satisfaction.” Environment and Behavior, Vol. 24, No. 5, pp. 670 - 679 .

Fleming, D. (2004) “Facilities management: a behavioural approach.” Facilities, Vol. 22, No. 1/2, pp. 35 - 43.

Franz, J. (1997) “The Indoor Plants.” In Menges, A. (ed.) LOG ID BGW Dresden. Opus.

Freeman, K. (2008) “Plants in Green Buildings.” Ambius White Paper - 01. Ambius University: Buffalo Grove, USA.

Giese, M., Bauer-Doranth, U., Langebartels, C., Sandermann Jr., H. (1994)

"Detoxification of formaldehyde by the spiderplant (Chlorophytum comosum L.) and by soybean (Glycine max L.) cell-suspension cultures,” Plant Physiology, Vol. 104, pp. $1301-1309$. 
Goodrich, R. (1982) The Perceived Office: The Office Environment as Experienced by its Users. In: Wineman, J. (1986) Behavioral Issues in Office Design. Van Nostrand Reinhold, New York. pp. 109 - 133.

Guo, H., Lee, S.C., Chan, L.Y., Li, W.M. (2004) "Risk assessment of exposure to volatile organic compounds in different indoor environments," Environmental Research, Vol. 94, No. 1, pp. 57 - 66.

Hanie, O., Aryan, A., MohammadReza, L., Elham, L. (2010). "Understanding the importance of sustainable buildings in occupants environmental health and comfort." Journal of Sustainable Development, Vol. 3, No. 2, pp. 194-200.

He, C., Morawska, L., Taplin, L. (2007) "Particle emission characteristics of office printers”, Environmental Science and Technology, Vol. 41, No. 17, pp. 6039 - 6045.

James, P. (2007) “Indoor green space: influences your health.” Senses, Brain and Space Workshop, Salford University, $8^{\text {th }}-9^{\text {th }}$ March 2007. Available at: http://www.rgc.salford.ac.uk/peterbarrett/p/?s=10\&pid=6 [Accessed: 10/08/2007].

Kaplan, R. (1993) “The role of nature in the context of the workplace.” Landscape and Urban Planning, 26, No. 1 - 4, pp. 193 - 201.

Karakitsios, S.P., Papaloukas, C.L., Kassomenos, P.A., Pilidis, G.A. (2007) "Assessment and prediction of exposure to benzene of filling station employees," Atmospheric Environment, Vol. 41, No. 40, pp. 9555 - 9569.

Kupritz, V. (1998) "Privacy in the workplace: The impact of building design." Journal of Environmental Psychology, Vol. 18, No. 4, pp. 341 - 356.

Kwallek, N., Lewis, C. M. (1990) "Effects of environmental colour on males and females: A red or white or green office.” Applied Ergonomics, Vol. 21, No. 4, pp. 275 $-278$.

Larsen, L., Adams, J., Deal, B., Kweon, B., Tyler, E. (1998) "Plants in the workplace: The effects of plant density on productivity, attitudes and perceptions." Environment and Behavior, Vol. 30, No. 3, pp. 261 - 281.

Leaman, A., Bordass, B. (2007) “Are users more tolerant of 'green' buildings?” Building Research and Information, Vol. 35, No. 6, pp. 662 - 673.

Lee, S.Y., Brand, J.L. (2005) "Effects of control over office workspace on perceptions of the work environment and work outcomes.” Journal of Environmental Psychology, Vol. 25, No. 3, pp. 323 - 333. 
Palanivelraja, S., Manirathinem, K.I. (2010). "Studies on indoor air quality in a rural sustainable home.” World Academy of Science, Engineering and Technology, Vol. 68, pp. 141-145.

Pech, R., Slade, B. (2006) "Employee disengagement: Is there evidence of a growing problem?” Handbook of Business Strategy, Vol. 7, No. 1, pp. 21 - 25.

Roelofsen, P. (2002) "The impact of office environments on employee performance: the design of the workplace as a strategy for productivity enhancement." Journal of Facilities Management, Vol. 1, No. 3, pp. 247 - 264.

Rogelj, J., Meinshausen, M. (2010) “Copenhagen Accord pledges are paltry.” Nature, Vol. 464, Issue 7292, pp. 1126-1128.

Rooley, R. (1997), "Sick Building Syndrome - the real facts: What is known, what can be done,” Facilities, Vol. 15, No. 1/2, pp. 29 - 33.

Sandler, L.M., Schiffman Kymer, R.I. (2010) "Copenhagen Accord: Outcomes, Next Steps and Business Implications.” Environmental Claims Journal, Vol. 22, No. 2, pp. 144-149.

Schempp, D. (1997a) “Concepts of Solar Architecture.” In Menges, A. (ed.) LOG ID BGW Dresden. Opus.

Schempp, D. (1997b) “Aspects of the architectural and interior design.” In Menges, A. (ed.) LOG ID BGW Dresden. Opus.

Shibata, S., Suzuki, N. (2002) "Effects of the foliage plant on task performance and mood.” Journal of Environmental Psychology, Vol. 22, No. 3, pp. 265 - 272.

Singh, A., Syal, M., Grady, S.C., Korkmaz, S. (2010). "Effects of green buildings on employee health and productivity." American Journal of Public Health, Vol. 100, No. 9, pp. 1665-1668.

Smith, A., Pitt, M. (2008) "Preference for plants in an office environment.” Healthy and Creative Facilities, Proceedings of the CIB W70 Conference in Facilities Management, Edinburgh, UK, $16^{\text {th }}-18^{\text {th }}$ June 2008, pp. $629-637$.

Smith, A., Pitt, M. (2011) "Healthy Workplaces: Plantscaping for indoor environmental quality.” Facilities, Vol. 29, No. 3/4, pp. 169-187.

Smith, A., Tucker, M., Pitt, M. (2011) "Healthy, productive workplaces: Towards a case for interior plantscaping.” Facilities, Vol. 29, No. 5/6, pp. 209-223.

Smith, M., Whitelegg, J., Williams, N. (1998) “Greening the Built Environment.” Earthscan Publications, London. 
Stone, N., English, A. (1998) "Task type, posters and workspace color on mood, satisfaction and performance.” Journal of Environmental Psychology, Vol. 18, No. 2, pp.175 - 185.

Stone, N., Irvine, J. (1994) "Direct or indirect window access, task type and performance.” Journal of Environmental Psychology, Vol. 14, No. 1, pp. 57 - 63.

Thomas-Mobley, L., Roper, K.O., Oberle, R. (2005), "A proactive assessment of sick building syndrome", Facilities, Vol. 23 No.1/2, pp.6-15.

Tong, D., Leaman, A. (1993) "Sick building syndrome: Strategies and tactics for managers.” Facilities, Vol. 11, No. 4, pp. $19-23$.

Veitch, J., Gifford, R. (1996) "Choice, perceived control and performance decrements in the physical environment." Journal of Environmental Psychology, Vol. 16, No. 3, pp. 269 - 276.

Warnock, A.C. (2007) "An overview of integrating instruments to achieve sustainable construction and buildings.” Management of Environmental Quality: An International Journal, Vol. 18, No. 4, pp. 427-441.

WCED (1987) “Our Common Future.” Report of the World Commission on Environment and Development. [online]. Available at: http://www.undocuments.net/wced-ocf.htm

Wells, M. (2000) "Office clutter or meaningful personal displays: The role of office personalization in employee and organizational well-being." Journal of Environmental Psychology, Vol. 20, No. 3, pp. 239 - 255.

Williams, P. (1998) “Air-conditioned environments: System faults affecting occupant productivity and well-being in Australian buildings," The Cutting Edge 1998. RICS Research.

Wolverton, B.C., Johnson, A., Bounds, K. (1989) "Interior landscape plants for indoor air pollution abatement: Final Report.” National Aeronautics and Space Administration, Report No. TM-101768. Available at: http://ntrs.nasa.gov/archive/nasa/casi.ntrs.nasa.gov/19930073077_1993073077.pdf (Accessed 14/01/2008).

Wolverton, B.C., Wolverton, J.D. (1993) "Plants and soil microorganisms: Removal of formaldehyde, xylene and ammonia from the indoor environment," Journal of the Mississippi Academy of Sciences, Vol. 38, No. 2, pp. 11 - 15.

Wright, A. (2005) “Colour in commercial interiors.” Facilities Management, Vol. 12, No. 5, pp. 22 - 23. 
Zeiler, W., Boxem, G. (2009). "Ventilation of sustainable schools: better than traditional schools?” ASHRAE Transactions 2009, Vol. 115, Part 2, pp. 815-823. 